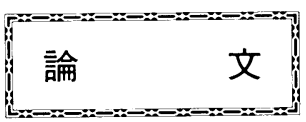

\title{
光環境における輝度の対比の定量的検討法
}

\author{
専門会員 中 村 芳 樹 (東京工業大学)
}

\section{A Technique for Quantitatively Examining Luminance Contrast in Lighting Environment} Fellow Member Yoshiki Nakamura (Tokyo Institute of Technology)

\begin{abstract}
Although it is highly desirable to be able to examine the contrast of luminance quantitatively in order to design an appropriate brightness pattern, conventional luminance contrast expressing methods can not be applied to the actual complicated luminance distribution. A previously proposed analysis method for expressing the luminance distribution was used to develop a technique for quantifying the contrast of luminance in an actual complicated luminance distribution. Application of this technique showed that it works well to actual distributions.
\end{abstract}

KEYWORDS : contrast, luminance contrast, lighting environment, quantitative representation, filtering

\section{1.はじめに}

光環境の計画，特に商業的な空間における照明計画では，空間 内に明暗の変化を意闵的に作り出し, 何らかの演出的な要素を含 んだ計画を行うことがしばしばである。照明計画の件数だけから いえば，均一に明るいことを第一の目的とした計画よりも，むし 万明暗の変化を意四的に作り出したものの方が多い.

一方これまで均一照明を目指してきたオフィスにおいても， 均一な照明がべストであるとは限らないと考えられはじめてい る。明視を確保するだけの照明から，プラスアルファとしての要 素を取り込む必要性が認識され，適度な不均一さを取り込んだ照 明計画も散兄されるようになった。状況にあった明暗の変化を意 四的に作り出すことは，従来以上に照明設計のもっとも重要な要 素の一つとなりつつある.

明暗の変化を積極的に取り込んだ照明計画では，多くの場合， 人の視線をそこに誘導したいという対象物があり，それを周辺よ りも明るく照明することによって目立たせ，人の注意を引き谷せ る。そのような対象物に与えられる照明は，周辺に比べて十分明 るくなければならないが，かといって極端に明るすぎては，空間 内の明るさ変化のバランスが崩れてしまう。

あるいは逆に, 周辺よりもやや暗い部分を作り出すことにより， 落ち着き感を醸し出したり，明るい部分と対比させて明暗を強調 したりなる場合もある。そのような場合もまた，それらの暗い部 分は適度に暗いことが重要なのであって，暗すぎてはせっかくの し夫が台無しになる。

明暗の変化を積極的に取り組んだ照明計画では，このように， 周辺の明るさとの関係を考虑しながら, 明るく照らす部分や暗く 残す部分の明るさレベルを微妙に調整することが必要であり，そ の調整が言わば，照明デザイナ一や照明コンサルタントの腕の見
せ所であると言えるだろう。

このような明るさの検討は, 対象物の反射率が異なったり，物 体の向きが異なったりすると同じ照明を与えてもその明るさが異 なることから，多くの場合輝度を用いて行われる。そしてその検 討を定量的に行拐うとすれば, 対象物の輝度と周辺の輝度との比, あるいは対象物輝度と背景輝度との对比を求めることになる。 ころがこれらの物理量を求めることは, 対象物やその周巡が複雑 な輝度の分布を持っているため難しく，結局，定性的な検封のみ に止めたり，極端に単純化した状沉を想定した上で定量的な検討 を行なうことになる。

このような現状を鑑み，筆者は複雑な輝度分布を定量的に検討 する方法を提案した ${ }^{112)}$. しかしそれらの諭文では，その方法論を 主な論点としたため, 提案した輝度分布の解析法が, 照明計画で どのように応用できるかを具体的に示さなかった。そこで本稿で は，提案した解析法を応用することにより，新たに，現実の光環 境において輝度の対比を检封する方法を提案する。

\section{2.輝度の対比を検討するための要件}

まず，輝度の対比を検討する具体的な事例として，図 1 の(a), (b)に示寸ような，机上にある木彫りの人形に施されたスポット照 明の効果を検討する場合を想定する。(a)，(b)とも，机上には天井 に据之付けられた白色蛍光灯によって $360[1 \mathrm{x}]$ の水平面照度が与 えられ，左上前方から照明されたスポットライトによって人形の 顔面には250［1x］の鉛直面照度（手前向き）が与えられている。 (a)では人形の背景に植裁が扔かれているため輝度の対比が大き く, (b)では背景に明度の高いポス夕一が見えているため輝度の対 比が小さくなっている。

輝度の対比は, (1)輝度比 (=対象物輝度 / 周辺輝度), もしくは, (2)輝度対比 $(=($ 対象物輝度一背景輝度 $) /$ 背景輝度 $))$ で定量的に 


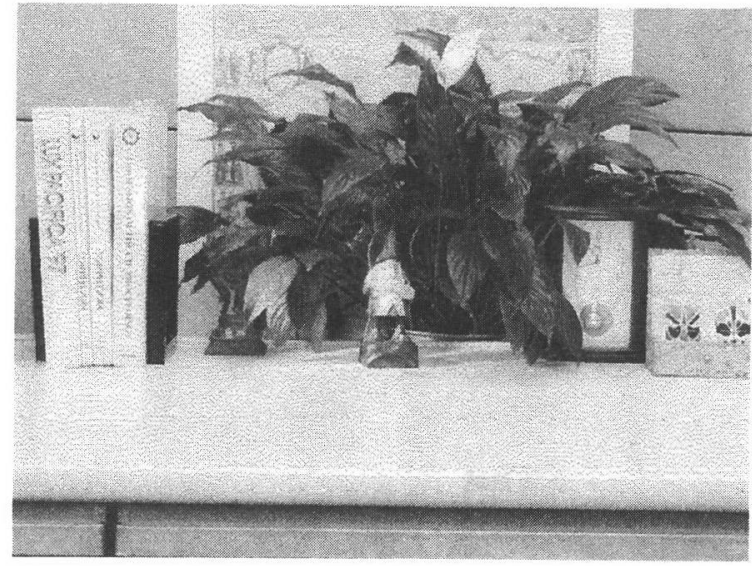

(a)背景に植栽がある場合

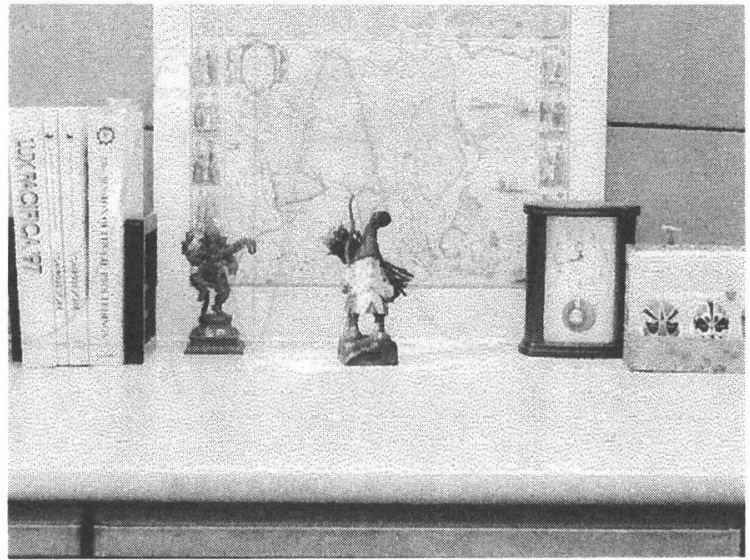

(b)背景にポスターが見える場合

図 1 輝度の対比を検討する画像

Fig. 1 Images for examining contrast of luminance.

示されることが普通である。これらを算出するためには，対象物 である人形の輝度と背景や周辺の輝度を得ることが必要となる が, 図 1 の画像から分かるように, 対象物である木彫りの人形の 表面, 背景, 周辺にはそれぞれ複雑な輝度分布が生じているため, 代表的な点を一つだけ取り上げて検討するというわけにはいか ず，一般的には，人形の表面，背景，周辺と思われる領域を設定 してその領域内の輝度を平均し, 人形の表面輝度, 背景輝度, 周 辺輝度とする.

このようにして求められた平均輝度の值は, 設定された領域の 範囲によって変化することは言うまでもないが, この領域を客観 的に設定することはむずかしい，たとえば図 1 の人形の輝度を求 める場合を考えてみると, 人形と背景の輝度の対比は, 主に人形 の明度の高い顔面部分と背景との対比であると考えられるが，人 形と背景という言葉だけから考之ると, 人形全体の平均輝度を求 めた方が良いような印象も受ける。対象物がもう少し大きく，一 部に照明が施されているような場合にはもっと判断が難しく，ど の部分を対象領域に含めるべきかは主観的に判断せざるを得なく なる.さらに背景領域の判断に至っては, 範囲を決める判断基準 が全くない.

このような場合の一つの解決方法として, 単純に領域内の平均 をとるのではなく,重み付け平均をとるという方法も考えられる. 通常, 対象部分と周辺部分の境界は微妙なものであり, この領域 の輝度の值は, 輝度の対比に対する寄与は小さいと考之られるか ら，このような境界の重み付けを小さくすることは理にかなって

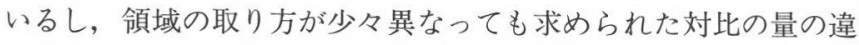
いは小さくなる．しかしこのような重み付け平均を考えるとする と,どのような重み付けを採用すべきかという問題が新たに生じ ることになる。

輝度の対比を定量的に検討する際のもう一つの問題は, 輝度分 布を測定する解像度の問題である. 輝度分布はディジタル画像と して測定されることになるが, 測定された各ドットの輝度の值は 測定装置の解像度に応じて既に平均化された值である。同じ対象 物であっても, 解像度を高くして測定すると, 一般に輝度変化の レンジは大きくなる.

このように考えていくと, 輝度比や輝度対比を定量的に検討す
るためには，(1)輝度分布を測定する解像度を設定し，(2)検討する 領域の大きさを客観的に決定し，(3)領域内の輝度を代表する值を 算出する，という三つの段階に対して，それぞれ適切な方法が示 されなければならないことがわかる。

\section{3. フィルタリングと輝度の対比}

輝度分布の画像は, さまざまな強さを持ったさまざまな粗さの 2 次元の輝度変化が合成されたものであると考えることができ, それぞれの輝度変化は 2 次元の三角関数の形で表すことができ る.どのような粗さの輝度変化が, どれだけの強さを持ってその 輝度分布を構成しているかを知りたい場合, 三角関数として表さ れた輝度変化の振幅を知ればよく, 輝度分布画像をフーリ工変換 してパワースペクトルをとることにより，それを知ることができ る. 一方, ある特定の粗さの輝度変化が, どの部分にどれだけの 強さで存在するかを知りたければ，その粗さの輝度変化だけを通 過させるフィルタをかければよく, その操作をフィルタリングと 呼ぶ3).

筆者は, 特定粗さの輝度変化だけを通過させる理想的なフィル 夕を提案し，それを用いて複雑な輝度分布を解析する方法を提案 した ${ }^{1)}$. 検出しようとする輝度変化の周波数を $f_{0}[\mathrm{cycle} / \mathrm{deg}]$ (す なわち波長を $\left.1 / f_{0}[\mathrm{deg}]\right)$ とすると, 筆者らの提案したフィル夕関 数は, 平面上の位置を $x, y$, 横方向, 縦方向の周波数成分を $u, v$ とすると,

周波数領域では

$$
\tilde{N}(u, v)=\frac{\left(u^{2}+v^{2}\right)}{f_{0}^{2}} \exp \left(1-\frac{\left(u^{2}+v^{2}\right)}{f_{0}^{2}}\right)
$$

実領域では

$$
N(x, y)=\pi^{3} f_{0}^{4}\left[\frac{1}{\pi^{2} f_{0}{ }^{2}}-\left(x^{2}+y^{2}\right)\right] \exp \left[1-\pi^{2} f_{0}^{2}\left(x^{2}+y^{2}\right)\right]
$$

と表される。

輝度分布画像をフィルタリングするには二つの計算方法ある。 一つは, 輝度分布画像をフーリ工変換し, その結果に式(1)を掛け, その後逆フーリ工変換を行うという方法であり, もう一つは, 輝 度分布画像に対し式(2)を用いてたたみ込みと呼ばれる計算を行う 方法である。 


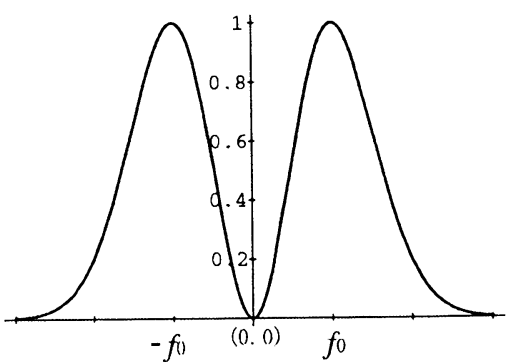

(a)周波数領域

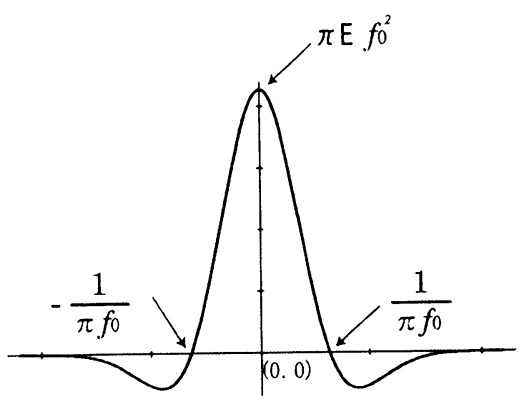

(b) 実領域

図2 フィルタ関数 N

Fig. 2 Filter function $\mathrm{N}$.

ここで後者の方法でフィルタリング計算を行う場合を考えてみ る.

離散的に測定され輝度分布画像 $I(k, l)$ に離散的に表現したフ イルタ $N$ をたたみ込む計算は次のように表される。

$I^{\prime}(m, n)=\sum_{k} \sum_{l} I(k, l) \bullet N(m-k, n-1)$

フィルタリングの操作では，このような計算を全ての点に対し て行うが，ここでこの計算をある特定の点 $(m, n)$ だけに注目した ものであると考えてみると, この計算は, 点 $(m, n) の$ 周囲の輝度 を，フィル夕関数によって重み付けし合計するという操作と同じ であることがわかる。筆者が提案した $N$ フィル夕は, 図2(b)に示 すように $(0,0)$ を中心とした点対称な分布を持ち, 中心部分が正, 周辺部分が負となる関数である。したがってこの計算は, 点 $(m$, n)を中心とした領域，すなわちフィル夕関数の值が正である領域 の重み付け合計と，周辺領域，すなわちフィル夕関数の值が負で ある領域の重み付け合計との差を取るという操作と同じである. そしてNフィル夕は全領域で積分すると 0 となるという性質を 持つことから，この点の周囲に輝度変化がなく一定の值をとる場 合，その計算結果は 0 となる.

このように, フィルタリングの計算は, 輝度分布の画像が輝度 の絶対值で表現されている場合, 中心領域と周辺領域の輝度の差 を求めていることになり，輝度分布画像が対数で表現されている 場合は, 中心領域と周辺領域の輝度の比を求めていることになる. この両者を合わせて，輝度の対比を算出しているという表現を使 うとすると, フィルタリングの計算は，画像上の全ての点に対し て，その点を中心にした輝度の対比を算出していることになり， その際の对象領域と周辺領域が, 困 2 (b)に示吉ような関数として 定義されていると言うことになる.

このような対象領域と周辺領域の設定がもっとも適切かどうか については今後検討する必要があるものの, 検討方る領域の広さ を客観的に定める方法としては理論的な背景があることから， $N$ フィルタによるフィルタリングを応用して輝度の対比を定量化す れば，前章で述べた輝度の対比を定量的に検討方る要件の内，(2) と(3)についてはクリアできる可能性がある.

次に, $N$ フィル夕によるフィルタリングを実際に計算しようと すると, $N$ フィル夕関数が局在してはいるものの無限の広がりを 持ち, 厳密な解を求めることができないことから, フィル夕関数 を何らかの形で近似しなければならない. $N$ フィル夕関数のよう なバンドパスフィルタを近似する場合, 周波数毎の重み付けの值

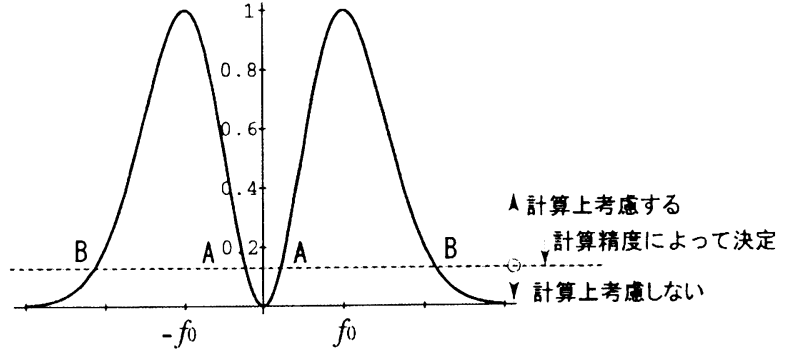

図3Nフィルタと計算精度

Fig. $3 \mathrm{~N}$-filter and calculation precision.

がある值より小さいものを無視するという方法をとることが通例 で, 具体的には, 図3の A より低い周波数や B より高い周波数は 存在しないとして計算を進める。この B を設定すること, すなわ ちフィル夕を通過するもっとも高い周波数を設定することは, 輝 度分布画像に含まれていなければならないもっとも高い周波数を 設定することにつながり，サンプリング定理より，輝度分布画像 を測定すべき解像度が決まることになる。したがって，実際のフ イルタリングの計算に当たって計算の精度を設定すれば, 前章の 要件(1)を満たすことになる。

このように，Nフィルタを用いたフィルタリングを忍用すれ ば，輝度の対比を定量的に検討するための方法を提案できる可能 性が高いことがわかる。

\section{4. 輝度の対比の定量的表現法}

前章で述べたように，Nフィルタを用いたフィルタリングを応 用して，検討したい対象を中心に $N$ フィル夕による重み付け加 算を行うという操作を考之れば, 周辺との輝度の対比を定量的に 検討するための指標が導入できる可能性がある，次にこの方法で 定量化される輝度の対比について考察してみる。

$N$ フィルタの重み付けが正となる範讲は，図 $2(\mathrm{~b})$ にるよう に, 検出周波数を $f_{0}$ とすると中心からの距離が $1 /\left(\pi f_{0}\right)$ 以下の領域 であり，検出周波数が決まれば一定の值となる。ここで，図４(a) のような対比を検討したい領域（对象領域）があり，その領域の 中心に点 $(m, n)$ を取り, 検出周波数を変化させて $N$ フィル夕に よる重み付け加算を行った場合を考之てみる。四4(b)には，検出 周波数が異なった場合の $N$ フィル夕による重み付けの変化を示 す。ここでは問題を単純化するために，1次元の変化だけを取り 
上げてある。

(1)に示される検出周波数が高い場合，言い換えれば検出波長が 短い場合には，フィル夕関数の值は主に対象領域内で変化导るこ とから，演算結果は0に近いものとなる。また検出波長が長い(3) の場合も, 演算結果は正の值となるもののその值はかなり小さい. これに対して(2)では, フィル夕関数の正となる領域と対象領域と が一致しておう，この場合の演算結果は，検出波長を連続的に変 化させて $N$ フィル夕による重み付け加算を行った際の最大值と なる。

検出波長を連続的に変化させて $N$ フィル夕による重み付け加 算を行ったこのような様子は，具体的には図 5 のように表現され る. 対象領域が周辺領域より明るい場合は実線で示すように，対 象領域が周辺領域より暗い場合には破線のようなグラフとして表 される.この変化の様子はもち万ん，对象領域や周辺領域の輝度 分布によって異なるが, その絶対值の最大值は一意的に決めるこ とができる。そして，対象領域の中心点が特定できないような場 合でも, 中心付近の複数の点に対して上記演算を行い，各点で得 られる絶対值の最大值の大きさを比較することにより，絶対值の 最大值を一意的に決めることができると考えられる。

そこで筆者は, 対象領域内の点に対して, 検出波長を連続的に 変化させて $N$ フィルタによる重み付け加算を行った結果得られ る絶対值の最大值を, 対象領域と周辺領域の「主要な輝度の対比

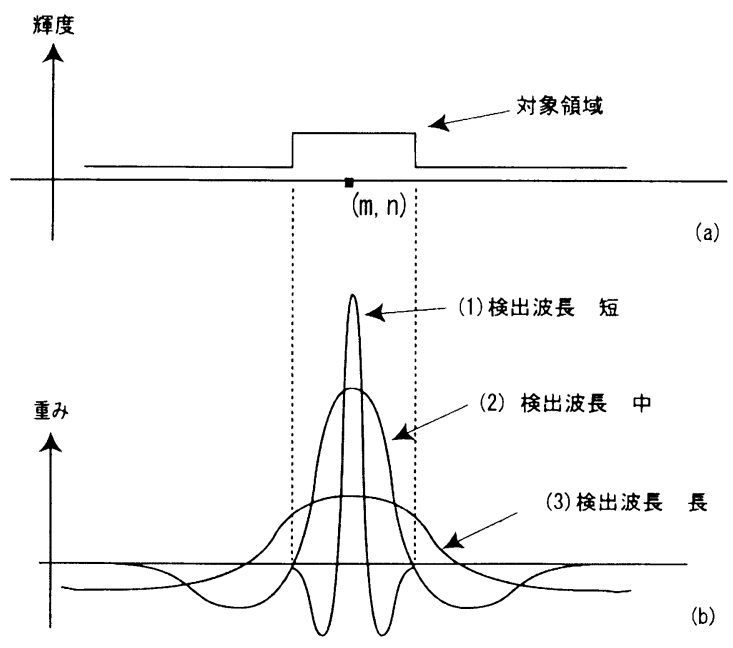

図4 対象部分の大きさと検出波長の大きさの関倸

Fig. 4 The relation between the size of a target part and the size of detec tion wavelength.

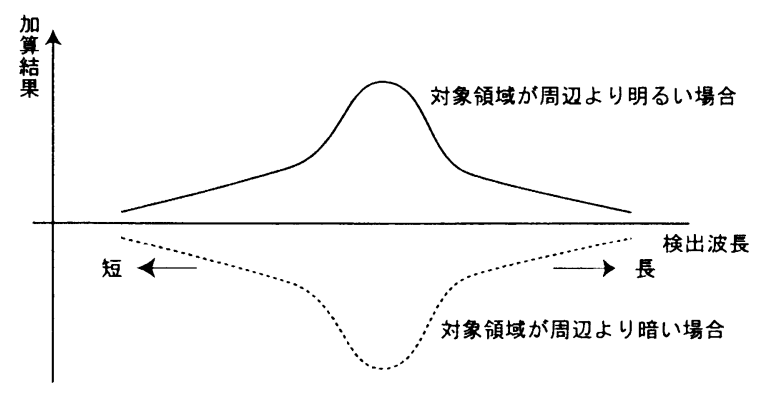

図 5 検出波長を变化させた場合の重み付け加算結果の变化

Fig. 5 Shifts of the weighting addition result at the time of changing detection wavelength. (principal luminance contrast)」として定義することを提案す る.この方法によれば，周辺との対比を検討したい対象が明らか であれば，輝度の対比を表す一つの定量的な指標を与えることが できる。

\section{5. 計算のための数値マトリックス}

実際の $N$ フィル夕による重み付け加算には, ある計算精度を 設定して計算することになるが，その際には，四３のAより低い 周波数やBより高い周波数は存在しないとして計算を進めるこ とになる．Bで示されるフィル夕を通過するもっとも高い周波数 からは輝度分布画像の測定解像度が (サンプリング定理より $\mathrm{B} の$ 2 倍の周波数となる)，Aに示されるもつとも低い周波数からは 重み付け加算の範讲が決如ら， $\mathrm{B}$ の周波数と $\mathrm{A}$ の周波数の関係 は，計算精度に忍じて設定される水平線の高さよって一意的に決 まることから，具体的な $N$ フィル夕による重み付けマトリック スは一つに決まることになる。そして検出波長を変化させながら 計算を進める手順は，まず検出波長を決め，計算精度に対応した 解像度で輝度分布画像を測定あるいは生成し，その画像にその計 算精度より与えられたマトリックスを用いて重み付け加算を行j というものになり，そのマトリックスは検出波長によらず一種類 でよい.

次に計算に必要なマトリックスを検討してみる。

表 1 の [B] 欄には，計算精度を変化させることによって，計算 対象とすべき周波数の範讲がどのように変化するかが示されてい る. そして必要解像度は, 考慮すべき最高周波数によって, 検出 周波数の逆数 (すなわち検出波長) に対する係数として $[\mathrm{C}]$ 欄の ように決まり，重み付け加算に必要なマトリックスの大きさは， 考慮すべき最低周波数と解像度の関係から [D] 欄のように決ま る.ここで $[\mathrm{C}]$ 欄に示された係数を解像度係数 $\alpha$, 検出波長を $L_{0}$ とすると, 具体的な必要解像度 $(R)$ は,

$$
R=\alpha \cdot L_{0} \cdots
$$

$$
\text { と表わされる。 }
$$

マトリックスが大きくなると計算負荷が増大することを勘案す ると, 表 1 より, 解像度係数 $\alpha$ の候補として0.3，0.35などが考之 られ，それぞれのマトリックスの大きさは $7 \times 7,5 \times 5$ となる. 加算するマトリックスは式(2)で示された関数を近似した值とな るが，式(2)は積分することができ，下記のようになる。

$$
\frac{1}{4} \sqrt{\pi} f_{0}\left(y \bullet \exp \left(1-f_{0} \pi^{2} y^{2}\right) \bullet \operatorname{erf}\left(f_{0} \pi x\right)+x \bullet \exp \left(1-f_{0} \pi^{2} x^{2}\right)\right.
$$

- $\left.\operatorname{erf}\left(f_{0} \pi y\right)\right)$

ここで $\operatorname{erf}(\boldsymbol{z})$ は䛊差関数であり, $\operatorname{erf}(z)=\frac{1}{\sqrt{\pi}} \int_{0}^{z} e^{-t^{2}} \mathrm{~d} t$ と定 義される。

この式(5)を用いて積分範囲を適切に設定することにより，ある 解像度で輝度分布が測定された場合のマトリックスの值を求める ことができる。

解像度係数 $\alpha$ を 0.3 おび 0.35 として計算したマトリックスを 表 2, 表 3 に示す。計算には Mathematica ver. 3 老用い, 小数点 以下第 5 位で四捨五入した值を示している.

このマトリックスは, 計算の簡便性から考えればできるだけ小 さい方がよい.しかし表 3 では，Nフィル夕の特徴であるメキシ カンハット型の分布が表現されていない。一方表 2 では, その特 徵はある程度保存されおり, 解像度係数 $\alpha$ 在 0.3 とることが適 切であると判断される。

表2のマトリックスをもう少し戦密に考えてみると, 式(2)を近 
表 1 計算精度とマトリックスの大きさ

Table 1 Calculation precision and the size of the matrix.

\begin{tabular}{|c|c|c|c|c|}
\hline$[\mathrm{A}]$ 欄 & \multicolumn{2}{|c|}{$[\mathrm{B}]$ 欄 } & {$[\mathrm{C}]$ 欄 } & {$[\mathrm{D}]$ 欄 } \\
\hline \multirow[t]{2}{*}{ 考虑する最低佃 } & \multicolumn{2}{|c|}{ 考虑すべき周波数の範囲 $\left(\times f_{0}\right)$} & 必要解像度 (解像度係数) & 計算に必要な \\
\hline & 低周波 (cycle/deg) & 高祘波 $($ cycle $/ \mathrm{deg})$ & $\left(\times L_{0}\right)[\operatorname{deg}]$ & マトリックスの大きさ \\
\hline 0.01 & 0.0608 & 2.7638 & 0.1809 & 90.9643 \\
\hline 0.05 & 0.1369 & 2.3966 & 0.2086 & 35.0125 \\
\hline 0.1 & 0.1955 & 2.2113 & 0.2261 & 22.6214 \\
\hline 0.2 & 0.2823 & 1.9986 & 0.2502 & 14.1606 \\
\hline 0.3 & 0.3536 & 1.8545 & 0.2696 & 10.4879 \\
\hline 0.4 & 0.4188 & 1.7385 & 0.2876 & 8.3031 \\
\hline 0.5 & 0.4816 & 1.6366 & 0.3055 & 6.7960 \\
\hline 0.6 & 0.5451 & 1.5416 & 0.3243 & 5.6566 \\
\hline 0.7 & 0.6120 & 1.4482 & 0.3453 & 4.7331 \\
\hline 0.8 & 0.6868 & 1.3507 & 0.3702 & 3.9334 \\
\hline 0.9 & 0.7800 & 1.2377 & 0.4040 & 3.1737 \\
\hline
\end{tabular}

$f_{0}$ : 検出周波数

$L_{0}$ : 検出波長 $\left(=1 / f_{0}\right)$

表 2 重み付けマトリックス(解像度係数 $\alpha=0.3$ )

Table 2 Weighting matrix (resolution coefficient $\alpha=0.3$ ).

\begin{tabular}{|r|r|r|r|r|r|r|}
\hline 0.0000 & -0.0002 & -0.0017 & -0.0032 & -0.0017 & -0.0002 & 0.0000 \\
\hline-0.0002 & -0.0063 & -0.0353 & -0.0563 & -0.0353 & -0.0063 & -0.0002 \\
\hline-0.0017 & -0.0353 & -0.0655 & 0.0625 & -0.0655 & -0.0353 & -0.0017 \\
\hline-0.0032 & -0.0563 & 0.0625 & 0.5728 & 0.0625 & -0.0563 & -0.0032 \\
\hline-0.0017 & -0.0353 & -0.0655 & 0.0625 & -0.0655 & -0.0353 & -0.0017 \\
\hline-0.0002 & -0.0063 & -0.0353 & -0.0563 & -0.0353 & -0.0063 & -0.0002 \\
\hline 0.0000 & -0.0002 & -0.0017 & -0.0032 & -0.0017 & -0.0002 & 0.0000 \\
\hline
\end{tabular}

表 3 重み付けマトリックス(解像度係数 $\alpha=0.35$ )

Table 3 Weighting matrix (resolution coefficient $\alpha=0.35$ ).

\begin{tabular}{|r|r|r|r|r|}
\hline-0.0016 & -0.0194 & -0.0402 & -0.0194 & -0.0016 \\
\hline-0.0194 & -0.0953 & 0.0014 & -0.0953 & -0.0194 \\
\hline-0.0402 & 0.0014 & 0.7019 & 0.0014 & -0.0402 \\
\hline-0.0194 & -0.0953 & 0.0014 & -0.0953 & -0.0194 \\
\hline-0.0016 & -0.0194 & -0.0402 & -0.0194 & -0.0016 \\
\hline
\end{tabular}

似しているための不都合が存在する。式(2)は無限大の範讲を積分 をすると 0 となるが, 表 2 のマリックスの係数を足し合わせて も0とはならず，二れは原曺像の平均值が出力に影響を方えると いうことを意味する。そこでマトリックスの合計を０とするため の補正を加えるとすると，表 2 に示された值を合計し，0からの 䛊差の $1 / 49$ をれぞれの值から引けばよいが，その場合，1/49が 割り切れないことから厳密に0とすることはできない.そこで本論 文では，マトリックス係数の合計が厳密に0 0 となことが必要と 考之，表 4 のような重み付けマトリックスを提案することにした。 その導出の手続きは，マトリックスの中央を除く各係数から表 2 の合計の $1 / 50$ を引き，中央の係数については合計の $2 / 50$ を減じた. したがって，厳密には，マトリックス中央の值は表 2 の䛊差の1/ 50だけ小さいことになる。このようにすれば，䛊差はあるものの，
計算対象領域の平均值の影響は全くなくなる。

表 4 は計算の簡便性を考えた結果であり，より簃密な解析が必 要な場合には，より大きなマトリックスを設定し，その係数を式 (5)から導出すべきであろう。

\section{6. 輝度の対比の検討例}

次に実際の輝度分布画像を対象に，本論文で提案する「主要な 輝度の対比」を実際に求め, 輝度の対比の大きさを検討してみる。 重み付けの計算には提案した表 4 のマトリックスを用いた。

四 1 (a)，(b)のシーンを，数段階に露出を変えて撮影寸ることに より, 輝度分布画像を作成した。作成にはデジタルカメラ(SONY DSC D700）を用い，絞りを5.6で固定，シャッタースピードを1 秒，1/8秒，1/60秒，1/500秒の 4 段階に変化させて撮影し，640× 480の画像として取り込んだ。取り込まれた闫像の RGB 值から輝 度への変換は，あらかじめ校正板を用いて作成した重问帰式を用 いた，輝度の测定範囲は $0.3\left[\mathrm{~cd} / \mathrm{m}^{2}\right] \sim 3390\left[\mathrm{~cd} / \mathrm{m}^{2}\right]$, 解像度は 0.0375 [deg]である.

輝度の対比を検討するためには，検出波長を連続的に変化させ てNフィル夕による重み付け加算を行う必要があるが, 実際の 分析では，女る解像度で予测定した輝度分布丽像を基に，その 解像度を幾つかのドットを平均守ることにより徐々に落としつ つ，それぞれの解像度ごとにNフィル夕による重み付け加算を 行い, その解像度に対㤁した検出波辰の輝度変化の強さ, 寸なわ ち輝度の対比を求めて行けばよい。ここでは $0.0375[\mathrm{deg}]$ の解像 度で測定された輝度分布画像を基に計算を進めたが，測定解像度 そのままではノイズが含まれている可能性があるため, オリジナ ルの輝度分布画像の縦, 横 2 ドットずつを平均したもの, 寸なわ ち解像度 0.075 [deg] の輝度分布画像をもっとも高い解像度とし て分析し，その後表 5 に示寸上うに，解像度を順次 2 倍に変化さ せて分析を行った。このような手続きで行った分析は，式(4)より， 表 5 に示すような $0.25 〜 8[\mathrm{deg}]$ に検出波長を設定して，輝度の 対比を検討したことになる。

ここではまず，輝度の対比の検討点を木彫りの人形の明度が高 
表 4 修正重み付けマトリックス

Table 4 Corrected weighting matrix.

\begin{tabular}{|r|r|r|r|r|r|r|}
\hline-0.000024 & -0.000224 & -0.001724 & -0.003224 & -0.001724 & -0.000224 & -0.000024 \\
\hline-0.000224 & -0.006324 & -0.035324 & -0.056324 & -0.035324 & -0.006324 & -0.000224 \\
\hline-0.001724 & -0.035024 & -0.065524 & 0.062476 & -0.065524 & -0.035024 & -0.001724 \\
\hline-0.003224 & -0.056324 & 0.062476 & 0.572752 & 0.062476 & -0.056324 & -0.003224 \\
\hline-0.001724 & -0.035024 & -0.065524 & 0.062476 & -0.065524 & -0.035024 & -0.001724 \\
\hline-0.000224 & -0.006324 & -0.035324 & -0.056324 & -0.035324 & -0.006324 & -0.000224 \\
\hline-0.000024 & -0.000224 & -0.001724 & -0.003224 & -0.001724 & -0.000224 & -0.000024 \\
\hline
\end{tabular}

表 5 平均したドット, 解像度, 検出波長の関係

Table 5 Relation of the averaged dots, resolution, and detection wavelength.

\begin{tabular}{|c|c|c|c|c|c|c|}
\hline 平均したドット数 & $2 \times 2$ & $4 \times 4$ & $8 \times 8$ & $16 \times 16$ & $32 \times 32$ & $64 \times 64$ \\
\hline 解像度 $[\mathrm{deg}]$ & 0.075 & 0.15 & 0.3 & 0.6 & 0.12 & 0.24 \\
\hline 検出波長 $[\mathrm{deg}]$ & 0.25 & 0.5 & 1 & 2 & 4 & 8 \\
\hline
\end{tabular}

い顔の部分の中心付近に設定し，輝度の対比の検討を進めた。

明度の高い木彫りの人形の顔の部分は，作成しな輝度分布画像 では30〜40ドット程度の大きさとなった。主要な輝度の対比は， 既に述べたように，重み付けマトリックスの正の領域が対集領域 と一致する付近の波辰で検出されると考えられので,

$(2 / \pi) \cdot L_{0}=(30 \sim 40) \times 0.0375[\mathrm{deg}] \quad\left(L_{0}\right.$ : 検出波長 $)$ を满たすような検出波長で主要な輝度対比が検出されると考えら れる.これより，檢出波長が1.767〜2.356 [deg] の付近で主要な 輝度対比が検出されることがわかる.

表 6 に，輝度の対数で表現された輝度分布画像を使って $N$ フ イルタによる重み付け加算を行い, 周辺と対象領域との輝度比を 算出した結果を示す。表よりわかるように，背景に植栽がある(a) の輝度分布では，予想通り検出波辰 $2[\mathrm{deg}]$ で明確なピークがあ り，最大值約3.46を取ることがわかる.一ノj, 背景にポス夕ーが ある(b)の場合は全体的に値が低く，明確なピークを持たないが， 検出波言 1 [deg] で最大值約 1.35 をとている.

表 7 には，輝度分布を輝度の絶対值で表現し，同様の演算を行 つた結果を示亦。この演算の場合，周辺輝度と対象輝度の差が抽 出されるが，このままでは明るさと皅接の対応関係を検討するに は不十分である。一般に輝度差を背景輝度で割ったものが輝度対
表 6 輝度比の検討結果

Table 6 Study result of luminance ratio.

\begin{tabular}{|c|c|c|c|c|c|c|}
\hline 検出波长 $[\mathrm{deg}]$ & 0.25 & 0.5 & 1 & 2 & 4 & 8 \\
\hline $\begin{array}{c}\text { (a)背景に植裁が } \\
\text { 女場合 }\end{array}$ & 1.073123 & 1.082147 & 1.38119 & 3.456742 & 2.294712 & 0.872108 \\
\hline $\begin{array}{c}\text { (b) 背景にボス } \\
\text { 早がある場 } \\
\text { 命 }\end{array}$ & 1.111339 & 1.140651 & 1.354678 & 1.322833 & 0.90337 & 0.862093 \\
\hline
\end{tabular}

比と定義され，この輝度対比と明視との関連は多くの研究で明ら かになっている4). しかしながら, 現奏の複雑な輝度分布考之る と，これまで述べたように，背景輝度を客観的に決めることはで きない，そこでここでは，演算を進める際に設定した計算精度に よって定義される計算範囲，すなわち計算マトリックスの大きさ の範网に打ける平均輝度をとり，この平均輝度によって，Nフイ ル夕による重み付け加算の結果得られた輝度差を割り，これを輝 度対比として表現した。

表よりわかるように，背景に植载がある(a)の場合の $2[\mathrm{deg}] を$ 检出波長とした輝度対比が顕著に大きく，この輝度対比が対象領 域の明るさ感を形作っていると考えることができる. 複雑な輝度 分布を対象にした場合, 従来のような定義では輝度対比を求女る ことができないことからこのような方法で輝度対比を検討する ことは有効であ万う。

次に, 対象領域の中心がずれている可能性を考え, 検出波長 2 [deg]に対応する必要解像度で生成された輝度画像で，中心点を 上下左右に 1 ドットずつ変化させて計算した結果が表 8 に示され ている。表中座標 $(0,0)$ に当たる部分が設定した中心点で計算し た輝度対比である。表より，設定した中心点はほぼ適当な位置で あったことがわかる。

\section{表 7 輝度対比の検討結果}

Table 7 Study result of luminance contrast.

(a)背衰に植裁がある場合

\begin{tabular}{|c|c|c|c|c|c|c|}
\hline 娭虹波長 [deg] & 0.25 & 0.5 & 1 & 2 & 4 & 8 \\
\hline 輝度差 $\left[\mathrm{cd} / \mathrm{m}^{2}\right]$ & 1.936453 & 2.16485 & 7.285597 & 19.19894 & 9.703657 & -3.550923 \\
\hline 平均輝度 $\left[\mathrm{cd} / \mathrm{m}^{2}\right]$ & 34.10969 & 32.35388 & 16.92982 & 8.15912 & 11.67811 & 19.08567 \\
\hline 輝度対比 & 0.05677 & 0.06691 & 0.43034 & 2.35306 & 0.83093 & -0.1861 \\
\hline
\end{tabular}

(b)背景にポス夕一がある場合

\begin{tabular}{|c|c|r|r|r|r|r|}
\hline 検出波長 $[\mathrm{deg}]$ & \multicolumn{1}{c|}{0.25} & \multicolumn{1}{c|}{0.5} & \multicolumn{1}{c|}{1} & \multicolumn{1}{c|}{2} & \multicolumn{1}{c|}{4} & \multicolumn{1}{c|}{8} \\
\hline 輝度差 $\left[\mathrm{cd} / \mathrm{m}^{2}\right]$ & 3.304208 & 3.502756 & 6.4545265 & 6.64641 & -3.18361 & -4.965729 \\
\hline 平均輝度 $\left[\mathrm{cd} / \mathrm{m}^{2}\right]$ & 33.87926 & 31.14469 & 23.74192 & 26.95424 & 31.7726 & 30.74522 \\
\hline 輝度対比 & 0.09753 & 0.11247 & 0.27186 & 0.24658 & -0.1002 & -0.1615 \\
\hline
\end{tabular}


表 8 中心位置の検討結果（輝度対比）

Table 8 Study result of center position (luminance contrast).

\begin{tabular}{|r|c|c|c|}
\hline & -1 & 0 & 1 \\
\hline-1 & 0.453701 & 1.197919 & -0.22084 \\
\hline 0 & 1.092154 & 2.353065 & 0.443706 \\
\hline 1 & 0.501293 & 1.725847 & 0.253216 \\
\hline
\end{tabular}

以上の計算の結果，木彫りの人形を対象領域として設定した場 合の主要な輝度の対比は,

㘡 1 (a)の背景に植栽がある場合

輝度比 3.456742

輝度対比 2.35306

(ただし検出波長 2 [deg］の時)

困 1 (b)の背景にポスターがある場合

輝度比 1.354678

輝度対比 0.27186

(ただし検出波長 1 [deg $]$ の時)

と定量化できた。

\section{7. まとめ}

照明設計の際，明るい部分と暗い部分の関係を適切に設計する 事は重要であり，ある対象と周辺との輝度の対比は，その検討の ための重要なツールである。しかし現実の複雑な輝度分布を対象 にした場合，輝度の対比を定量的に表現することはこれまででき なかったそそこで本論文では，複雑な輝度分布であっても輝度の 対比を定量化できる方法として,「検出波長を連続的に変化させて $\mathrm{N}$ フィルタによる重み付け加算を行い, その最大值をもって主要 な輝度の対比として表現する」という方法を提案した. そしてこ の方法を用いて，実際の輝度分布における輝度の対比の定量的な
検討を行い，その有効性を示した。

本稿では，輝度の対比が一つの量として確定できることに重点 を置き，上記のような定量的指標を提案した。しかしながら，検 出波長の変化につれて対比の量が変化する様子は，輝度の対比の 何らかの特性を表しているとも考えられ，今後このような点に焦 点を当てた検討も必要であると考えられる。

本研究を進めるに当たって，東芝ライテック怢)の鹿倉智明氏に は，輝度分布を測定し重み付け加算を行う際，多くのご協力をい ただいた。ここに記して深謝申し上げる。

\section{参 考 文 献}

（1） 中村芳樹，乾正雄，沢田敏実：輝度分布の表現法に関する 研究; 日本建築学会計画系論文報告集, [431], pp.1724 (1992).

（2）中村芳樹，乾正雄：視環境の輝度分布特性に関する研究； 日本建築学:会計画系論文報告集， [438]，pp.1-8（1992）。

（3）たとえば，辻内順平編著：応用画像解析，共立出版 (1981)。

（4）たとえば，伊藤克三，中根芳一，岩永克美; 日本建築学会 論文報告集号外, p.607 (1967).

(受付日 2000 年 4 月 11 日 /採録日 2000 年 6 月 1 日)

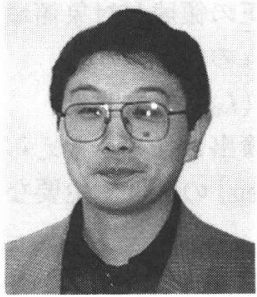

中村 芳樹 (専門会員)

東京工業大学大学院総合理工学研究科

昭和31年11月 4 日生まれ。昭和 61 年 3 月東 京工業大学大学院社会開発工学専攻修了。同 年東京工業大学助手, 平成 5 同大学助教授。 工学博士. 専門は視環境評価, 環境心理学. 日本建築学会, 日本 色彩学会, 日本感性工学会, MERA 会員。 